\title{
ОСОБЛИВОСТІ ФУНКЦІОНУВАННЯ ТА МОДЕЛІ БІЗНЕСУ НА РИНКУ ЕЛЕКТРОННОЇ КОМЕРЦІї В УКРАЇНІ
}

\section{ОСОБЕННОСТИ ФУНКЦИОНИРОВАНИЯ И МОДЕЛИ БИЗНЕСА НА РЫНКЕ ЭЛЕКТРОННОЙ КОММЕРЦИИ}

\author{
KEY FEATURES AND BUSINESS MODELS IN E-COMMERCE MARKET IN \\ UKRAINE
}

В статті було визначено передумови та ключові чинники, щзо впливають на функиіонування ринку електронної комериії, виділено його характерні особливості, зокрема - міжнародний характер, високу залежність від розвитку технологічної бази, постійну зміну форматів взаємодії гравиів, відставання законодавчого регулювання від реального стану ринку, тощз. Виділено основні характеристики ринку, такі як короткі терміни впровадження продукту на ринок, иирокий вибір товарів та послуг, можливість порівняння характеристик двох та більше товарів, зручність придбання, економія часу тощо. Проведено порівняльний аналіз з ринками Європейських краӥн. Розглянуто особливості та узагальнено ключові моделі бізнесу, що використовуються на ринку. Зокрема, нові моделі, щзо базуються на характері взаємовідносин зі споживачем - дизайнери споживчого досвіду, генератори потоку, будівники брендів, тощьо. На основі аналізу та проведеного експертного опитування було виділено ключові позитивні та негативні тендениії, щуо формують ринок електронної комериії, $i$, як підсумок, виділено ключові проблемні питання, щзо потребують вирішення, в тому числі - вдосконалення нормативної бази, впровадження системи підготовки персоналу тощо.

Ключові слова: електронна комерція, досвід споживача (користувача), електронний бізнес, бізнес модель.

В статье были определены предпосылки и ключевые факторы, влияюшие на функциионирование рынка электронной коммериии, выделены его характерные особенности, в частности - международный характер, высокую зависимость от развития технологической базы, постоянное изменение форматов взаимодействия игроков, отставание законодательного регулирования от реального состояния рынка и тому подобное. Выделены основные характеристики рынка, такие как короткие сроки внедрения продукта на рынок, широкий выбор товаров и услуг, возможность сравнения характеристик двух и более товаров, удобство приобретения, экономия времени и т.n. Проведен сравнительный анализ с рынками европейских стран. Рассмотрены особенности и обобщены ключевые модели бизнеса, используемых на рынке. В частности, новые модели, основанные на характере взаимоотнотений с потребителем - дизайнеры потребительского опьта, генераторы потока, строители брендов, и тому подобное. На основе анализа и проведенного экспертного опроса были выделены ключевые позитивные и негативные тенденции, формирующчие рынок электронной коммерции, и, как итог, выделены ключевые проблемные вопросы, требующие решения, в том числе - совершенствование нормативной базы, внедрение системы подготовки персонала. 
Ключевые слова: электронная коммериия, потребительский опыт (пользователя), электронный бизнес, бизнес модель.

In the article the prerequisites and key factors influencing the functioning of the e-commerce market were identified, its specific features, in particular, the international character, high dependence on the development of the technological base, the constant change in the formats of interaction of players, the lag of legislative regulation from the real state of the market. The basic characteristics of the market are identified, such as short terms of product introduction to the market, a wide range of goods and services, the ability to compare the characteristics of two or more products, the convenience of purchasing, saving time, etc. A comparative analysis is carried out with the markets of European countries. Features and summarizes the key business models used in the market. In particular, new models based on the nature of the relationship with the consumer the designers of consumer experience, flow generators, brand builders, and the like. Based on the analysis and expert survey, the key positive and negative trends that shape the e-commerce market were highlighted and, as a result, key problem issues that need to be addressed are highlighted, including the improvement of the regulatory framework and the introduction of the personnel training system.

Keywords: e-commerce, consumer experience (user), e-business, business model.

Вступ. Останні роки показують, що з кожним роком інтернет все більше проникає у життя людей. Незабаром інтернет знайде своє місце в усіх сферах сучасного бізнесу, в якому працюють такі бізнес-моделі, які у реальному житті й уявити собі неможливо. Вже зараз відчувається, що інтернет стає атрибутом ділового життя кожного, хто прагне процвітати і поліпшити економічну ситуацію в країні. Інтернет у наші часи - це ціла індустрія, яка швидко проникає у всі галузі людської діяльності. Саме зараз ця індустрія знаходиться у стадії стрімкого зростання, яке збережеться у найближчі десятиліття. Величезна кількість компаній у всьому світі бачать в інтернеті великий комерційний потенціал та можливість переводу свого бізнесу на якісно новий рівень. Тому в Україні стрімко розвивається ринок електронної комерції. Проте до цього часу переважна більшість досліджень охоплювала загальну статистику ринку, кількість гравців, темпи його розвиту тощо. Зокрема, проблематика цифрових ринків розглядалась в роботах розглядають в своїх роботах Шнайдер Г., Шалева О.,І., Окландер М.А., Ілляшенко С.М. та інші Але стрімкі зміни, що відбуваються на ринку потребують більш детального узагальнення принципів функціонування ринку, формалізації моделей бізнесу та маркетингових стратегій, що використовуються на ринку електронної комерції в Україні.

Постановка завдання. Мета дослідження полягає в визначенні передумов та ключових чинників, що впливають розвиток та функціонування ринку електронної комерції в Україні та моделей бізнесу, які характері для даного ринку.

Методологія. Основу наукового дослідження становлять загальні та спеціальні методи наукового пізнання: методи теоретичного узагальнення та порівняння, методи системного аналізу.

Результати дослідження. Поняття електронної комерції вперше з'явилось на сторінках вітчизняної преси близько 15 років тому, проте й досі ще формується у розумінні українців. Згідно Закону України «Про електронну комерцію», електронна комерція (від англ. - e-commerce) - відносини, спрямовані на отримання прибутку, що виникають під час вчинення правочинів щодо набуття, зміни або припинення цивільних прав та обов'язків, здійснені 
дистанційно 3 використанням інформаційно-телекомунікаційних систем, внаслідок чого в учасників таких відносин виникають права та обов'язки майнового характеру [1]. Гаррі Шнайдер у своїй роботі «Electronic Commerce» зазначав, що це сфера цифрової економіки, що включає всі фінансові та торгові транзакції, які проводяться за допомогою комп'ютерних мереж, та бізнеспроцеси, пов'язані з проведенням цих транзакцій [2].

Часто відбувається плутанина двох базових понять: електронної комерції та електронного бізнесу. Згідно визначенню фахівців компанії IBM, електронний бізнес - це проведення основних бізнес-процесів за допомогою інтернет-технологій. Таким чином, електронним бізнесом ми називаємо будьяку ділову активність, що використовує можливості глобальних інформаційних мереж для перетворення внутрішніх і зовнішніх зв'язків з метою створення прибутку [4].

Отже, електронна комерція $€$ найважливішим складовим елементом електронного бізнесу. До неї відносять електронний обмін інформацією (англ. Electronis Data Interchange), електронний рух капіталу (англ. Electronic Funds Transfer), електронну торгівлю (англ. E-Trade), електронні гроші (E-Cash), електронний маркетинг (англ. E-Marketing), електронний банкінг (англ. ЕBanking), електронні страхові послуги (англ. E-Insurance) тощо.

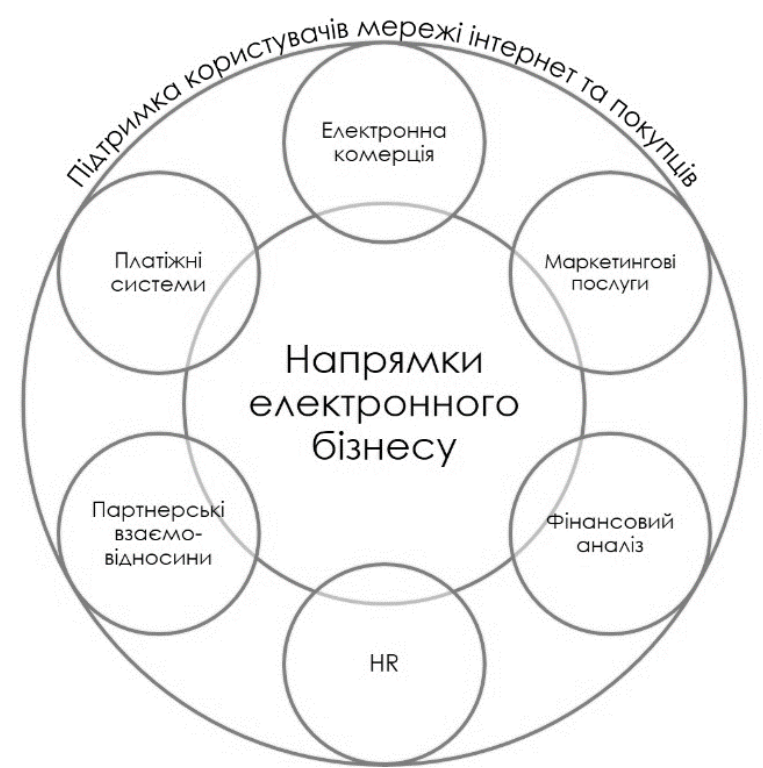

Рис. 1. Основні напрямки сучасного електронного бізнесу [4]

Розглянемо ключові показники ринку. Так, рівень проникнення Інтернету в Україні становить 62\% і відповідно до даних Factum Group Ukraine, за останні півроку (в порівнянні з даними вересня 2015 року), проникнення інтернету зросла на 7\% (або 4\% в абсолютних цифрах) - $358 \%$ до 62\% (рис. 2). За даними компанії Deloitte, приріст цього показника буде знижуватися в наступні роки за аналогією з тенденціями розвитку західних ринків. 


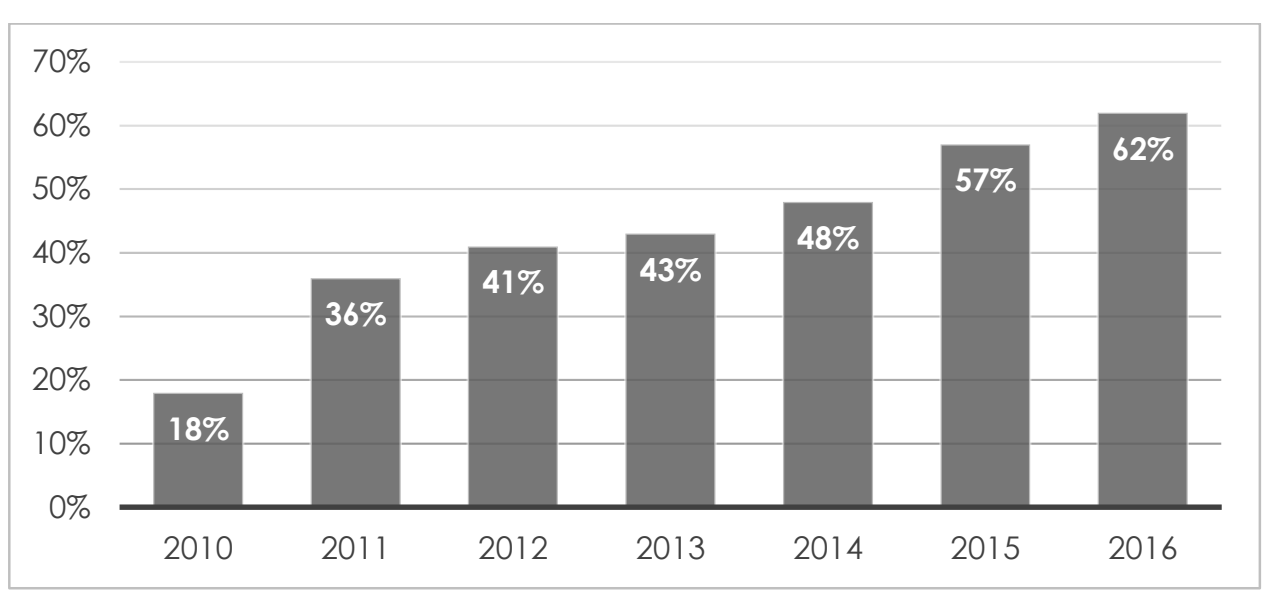

Рис. 2. Динаміка рівня проникнення інтернету в Україні [9]

Україна вже досягла достатнього рівня проникнення інтернету, аналогічного тому, що існує в найближчих країнах Центральної Свропи і Росії.

Характерно, що в структурі користувачів інтернету:

- більше третини користувачів - українці віком до 29 років;

- майже половина сільських жителів мають доступ до мережі Інтернет;

- у великих містах України інтернет-аудиторія становить 69\% загальної кількості населення, i за цим показником Україна наближається до середньоєвропейських значень.

Проаналізувавши основні характеристики розвитку ринку електронної комерції для Польщі, Нідерландів та Росії, на основі дослідження «The State of E-commerce», результатами якого на Ukrainian E-commerce Congress 2016 ділився професор Jesse Weltevreden, директор досліджень Ecommerce Foundation [3], отримуємо порівняльну таблицю.

Таблиия

Порівняльна таблиця основних характеристик розвитку ринку електронної комерції України, Польщі, Росії та Нідерландів

\begin{tabular}{|l|c|c|c|c|}
\hline & Україна & Польща & Росія & Нідерланди \\
\hline $\begin{array}{l}\text { Рівень проникнення } \\
\text { інтернету }\end{array}$ & $62 \%$ & $65 \%$ & $70 \%$ & $98 \%$ \\
\hline $\begin{array}{l}\text { Кількість онлайн- } \\
\text { покупців }\end{array}$ & 4 млн. & 12 млн. & 30 млн. & 12,9 млн. \\
\hline$\%$ від населення & $9,5 \%$ & $31 \%$ & $20,8 \%$ & $75,9 \%$ \\
\hline
\end{tabular}

Таким чином, можемо зробити висновок, що Польща та Росія мають найбільш схожі з Україною моделі розвитку електронної комерції.

На сьогодні 35\% українців є користувачами смартфонів (в 2015 році $28 \%$ ). Серед молодих людей у віці до 35 років ця цифра вище - $72 \%$ молодих українців використовують смартфони. В цілому з 2013 року число користувачів смартфонів в Україні зросла на 150\%. Зважаючи на це перед гравцями ринку екоммерс стоїть нагальна потреба адаптування сайтів до мобільних пристроїв та створення мобільних додатків.

Українці використовують свої смартфони переважно для пошуку інформації (45\%), доступу в соціальні мережі (42\%) і перегляд онлайн-відео $(37 \%)$. 
У 2016 році на одного українця в середньому припадає 1,2 підключений до інтернету пристрій, що на 58\% більше в порівнянні з 2013 роком. I українці активно цим користуються. Так, $61 \%$ українців звикли користуватися своїми смартфонами під час перегляду телевізора, а 35\% телеглядачів віком до 35 років сидять в інтернеті $з$ другого пристрою під час перегляду телевізора. Це відкриває нові можливості для мобільної реклами та використання кроссканальної комунікації для гравців ринку е-коммерс.

$51 \%$ українських користувачів інтернету шукають інформацію про будьяких продуктах як мінімум раз на місяць. А $36 \%$ українців у віці до 35 років шукають інформацію про товари на своєму смартфоні так само часто, як на комп'ютері.

Більшість представників бізнес-кіл починають переосмислювати свою комерційну діяльність і дедалі більше схилятися до використовування можливостей інтернет-простору, який $\epsilon$ інструментом для отримання високого прибутку.

У квітні-травні 2017 року нами було проведено експертне опитування гравців ринку електронної комерції. Для експертного інтерв’ю було обрано 20 респондентів, що представляють електронну комерцію в різних товарних категоріях (техніка та електроніка, одяг та взуття, косметика та парфумерія, книги, дитячі товари, білети, замовлення їжі). Та таких, що представляють різні моделі електронного бізнесу та сервісні компаній на ринку - інтернет-магазини, логістичні послуги для ринку е-коммерс, дошки оголошень, цінові агрегатори,

Головними характерними рисами бізнесу на ринку електронної комерції $\epsilon$ економія часу для клієнта та економія ресурсів для власника інтернет-магазину. Спираючись на це та результати дослідження, можемо виділити наступні особливості функціонування ринку електронної комерції, через виділення позитивних та негативних факторів функціонування на ньому:

- короткі терміни впровадження продукту на ринок електронної комерції (найменше - 3 дні) [6];

- широкий вибір товарів та послуг - інтернет-торгівля може оперувати товарами, яких ще немає у наявності, але можна зробити передзамовлення. завдяки діяльності інтернет-магазинів, у споживачів україни є доступ до актуальних пропозицій з усього світу;

- можливість демонстрації всіх характеристик товару. здатність швидше реагувати на ринкові умови: оперативно змінювати асортимент, ціни, описи товарів і послуг, надавати відгуки та відео-презентації, що демонструють сам товар та можливості його застосування;

- можливість оперативного аналізу реакції покупців на ті чи інші пропозиції, що дозволяє одержувати додаткову інформацію про їхні потреби і негайно вносити необхідні корективи в стратегію комунікації;

- за допомого сервісів для аналізу трафіку на сайті, стає можливим створення деталізованої бази даних споживачів, що дозволяє з великою ймовірністю визначати покупця для будь-якого товару;

- зручність придбання товарів. споживачі можуть порівнювати різні моделі одного й того ж товару, зіставляти їх ціни і замовляти вибраний товар 24 години на добу, не виходячи 3 дому; покупки в інтернеті відбуваються 
надзвичайно легко і без зайвих свідків, покупцеві ніщо не заважає i не дратує, ніхто не відволікає його від процесу купівлі (у тому числі й продавці);

- часто покупка через інтернет - єдина можливість відшукати унікальну річ в місті, країні (і навіть у світі) або придбати який-небудь пікантний товар конфіденційно.

Проте на ринку електронної комерції існують фактори, що ускладнюють його функціонування:

- Складність юридичного оформлення діяльності. Юридична база ще формується i має багато слабких місць. Наприклад, деякі положення суперечать вже існуючим законам у банківській та страховій сферах, не має чітких пунктів про врегулювання конфліктів між двома сторонами електронного договору тощо.

- Базове розуміння принципів інтернет-маркетингу. Недостатній рівень знань та досвіду переважної кількості власників інтернет-магазинів.

- Інтернет приваблива платформа для шахраїв, що пов'язано з використанням у діяльності комп’ютерних систем, на яких базуються електронні гаманці та електронні перекази, які стають привабливою здобиччю для хакерів.

- Неможливість фізично оцінити товар. Часто такі ситуації і призводять до виникнення конфліктів між продавцем та покупцем. Для вирішення таких проблем інтернет-магазини створюють шоу-руми або продають товар на умовах оплати товару після отримання, розвивають системи візуалізації, віртуальної примірки та відзивів задоволених споживачів.

- Страх підробок та шахрайства, особливо в сфері оплати.

Серед основних моделей бізнесу електронної комерції, 3 точки зору узгодження економічних інтересів, виділяють:

1. Бізнес - бізнес (business-to-business, В2B) - комерційна взаємодія між бізнесовими компаніями (підприємствами) - виробниками, оптовими посередниками, оптовими клієнтами щодо здійснення оптових закупівель та поставок товарів;

2. Бізнес - держава (business-to-government, B2G) - ділові зв'язки комерційних структур 3 державними організаціями (зокрема проведення державних закупівель через мережу Internet);

3. Бізнес - споживач (business-to-consumer, В2C) - електронна роздрібна торгівля та інші аспекти взаємодії зі споживачем. У цьому випадку має місце комерційна взаємодія між електронним магазином та покупцем - безпосереднім споживачем товару;

4. Споживач - споживач (consumer-to-consumer, C2C) - взаємодія споживачів для обміну комерційною інформацією (щодо придбання того чи іншого товару чи про співпрацю з певною фірмою) або роздрібна торгівля між фізичними особами;

5. Споживач - держава (consumer-to-government, C2G) - організація взаємодії між споживачами та державними структурами (особливо в соціальній та податковій сфері) [4]. 
6. Співробітник-співробітник (employee-to-employee, E2E) - організація взаємодії між співробітниками компанії за допомогою електронних ресурсів форумів, закритих груп в соціальних мережах, тощо.

7. Бізнес-співробітник (business-to-employee, B2E) - використання електронних ресурсів компанією для вирішення завдань управління персоналом та формування бренду роботодавця та інших - корпоративні університети онлайн, внутрішні корпоративні портали.

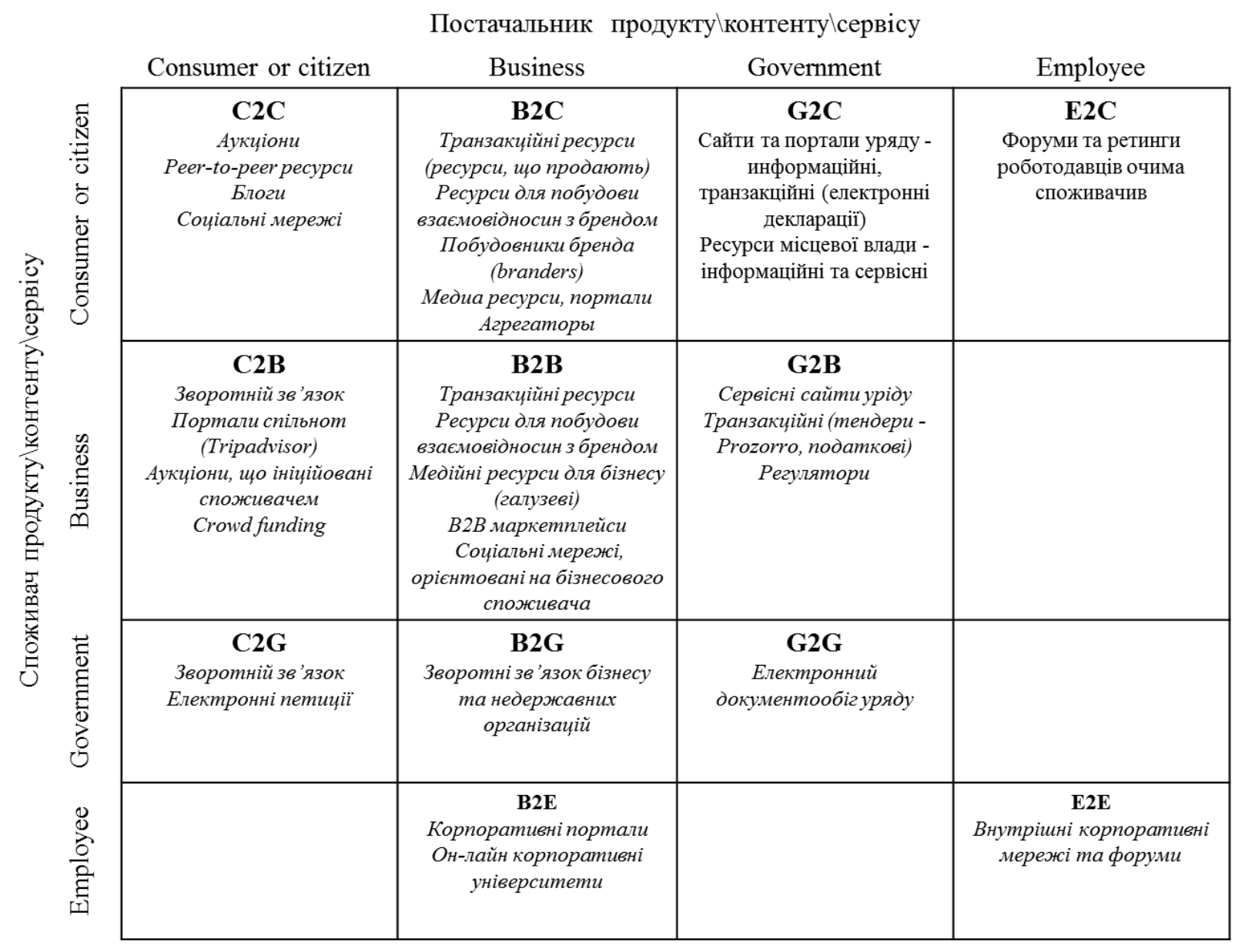

Рис. 3. Моделі бізнесу електронної комерції [7, Адаптовано та доповнено авторами]

Розглянемо більш детально сферу В2С, яка використовує в своїй діяльності таку модель як інтернет-магазин .

Інтернет-магазин - це автоматизована торгова система, що функціонує цілодобово та забезпечує ведення всього комплексу торгово-облікових операцій. Він має свою веб-вітрину 3 каталогом товарів і функціями 3 обслуговування покупців, яка знаходиться в інтернеті на веб-сайті.

В залежності від характеру взаємодії зі споживачем, можна виділити такі моделі бізнесу в сфері В2С [8]:

1. Побудовники брендів (branders): переважно в сфері реалізації споживчих товарів, хоча є цікаві приклади і в сфері В2В;мета - підвищити капітал бренду та залученість споживачів.

2. Дизайнери споживчого досвіду. (Consumer Experience (CX) або User Experience (UX)) : аналізують досвід споживача та створюють нові сервіси, що орієнтовані на цей досвід; орієнтовані на діалог зі споживачем; 
прикладом може слугувати ресурс Pet cube, призначений для спостереження та гри з домашніми улюбленцями на відстані - український старт-ап, що отримав значні інвестиції на краудфандинговій платформі Kicksterter.

3. Генератори попиту: переважно ритейл; конвертують трафік у продажі, збільшуючи частку у гаманці клієнта; яскравим прикладом втілення на такої стратегї українському ринку є Розетка.

4. Продуктові новатори: нові цифрові продукти та сервіси, переважно у вигляді цифрових продуктів.

Таким чином, враховуючи дві змінні - ступінь інноваційності продуктуلпослуги та ступінь новизни споживчого досвіду, можна запропонувати модифікацію матриці Ігоря Ансофа на основі показників товар\споживчій досвід (рис. 4).

\begin{tabular}{|c|c|c|c|}
\hline \multirow{4}{*}{ 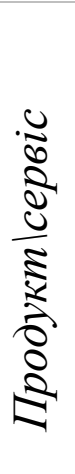 } & \multicolumn{3}{|c|}{ Споживчий досвід } \\
\hline & & існуючий & новий \\
\hline & існуючий & Генератори попиту & СХ дизайнери \\
\hline & новий & Продуктові новатори & Прориви \\
\hline
\end{tabular}

Рис. 4. Модель товар\споживчий досвід. Джерело: власна розробка

За допомогою проведення методу експертного інтерв’ю було визначено рейтинг проблем, які гальмують розвиток ринку електронної комерції в Україні:

- навантаження через оподаткування, постійні штрафи, санкції, перевірки та візити. прийняття закону про фіскалізацію гарантійних товарів;

- відсутність на ринку потужних міжнародних платіжних систем та недостатній розвиток національних, великі комісіі;

- низький рівень життя населення, зниження платоспроможності та відсутність довіри до розрахунків онлайн;

- нестабільність ситуації. воєнні дії на сході України;

- якість покриття мобільної мережі, низька швидкість 3G-інтернету;

- низький рівень автоматизації ключових процесів (складський облік, логістика, ціноутворення);

- недостатня кількість кваліфікованих кадрів та поганий стан доріг.

Також на основі опитування експертів було визначено комплекс дій інтернет-магазинів, що вони планують на найближчий час:

- збільшення бюджету на інтернет-маркетинг, використання SEO-просування, контекстної реклами та соціальних мереж у повній мірі; 
- адаптування сайту до різних мобільних пристроїв, підвищення рівня «юзабіліті», додання цікавих фішек, таких як 3D-демонстрація товару;

- персоналізована робота 3 клієнтом та використання BigData у своїй діяльності;

- скорочення строків доставки, розвиток функції повернення товару;

- розширення асортименту та вихід на міжнародний ринок.

Висновки. Отже, ринок електронної комерції - це мета-ринок, що включає в себе не лише продавців та покупців, а й сервісних операторів - логістичні служби, фінансові послуги, маркетингових та цифрових посередників (зокрема - пошукових, маркетингових, тощо). Ринок є міжнародним, і включає в себе в тому числі міждержавне переміщення товарів та послуг під впливом не лише внутрішнього, а й зовнішнього попиту, і пропозиції. Розвиток ринку в значній мірі пов'язаний 3 розвитком технологічної бази, розвитком цифрового рекламного ринку та IT-сфери. Механізми функціонування вже мають чітко виражені відмінності від традиційних ринків, проте ще знаходяться на етапі формування, що стосується інфраструктури ринку, законодавства тощо. Так, змінюється структура посередників, деякі зникають на місці яких утворюються нові, наприклад, прайс-агрегатори, інформаційні портали та ін. Все частіше відбувається інтегрування онлайн та оффлайн бізнесів, прослідковується розвиток омніканальності - об’єднання усіх каналів продажів в єдину систему, щоб клієнту було зручно автоматично переключатися з одного виду купівлі та спілкування на інший. В таких умовах і сам споживач стає активним учасником ринку. Він диктує свої правила, щодо контенту який хоче отримувати, оголошень, на які буде звертати увагу та сам генерує значну частину контенту.

В роботі було розвинуто теоретичні положення стосовно моделей бізнесу, що існують на ринку електронної комерції та моделей роботи на ринку в залежності від ступеню новизни товару та споживчого досвіду а також на основі експертного дослідження, було виявлено ключові позитивні та негативні чинники ринку, що дозволило запропонувати напрями подальшолго розвитку ринку. Все це створює додатковий інструментарій для практичної роботи на ринку електронної комерції в Україні.

\section{Література:}

1. Закон України "Про електронну комерцію" [Електронний ресурс]. - 2015. - Режим доступу до ресурсу: http://zakon3.rada.gov.ua/laws/show/675-19.

2. Шнайдер Г. Electronic Commerce / Гаррі Шнайдер. // Course Technology. - 2008.

3. Weltevreden Jesse, The State of E-commerce, ([Електронний ресурс] - Режим доступу до ресурсу: https://rive.google.com/file/d/0B6-0KXLfOXsQQzVjaDRyaFRRbHM/view.

4. Шалева О. І. Електронна комерція. Навч. посіб. - К.: Центр учбової літератури, 2011. $-216 \mathrm{c}$.

5. Особливості електронної комерції [Електронний ресурс] - Режим доступу до pecypcy: http://finance-dom.ru/marketing/81/404.

6. Баценко Д. Внутрішні дослідження Deloitte // E-commerce Congress. - жовтень, 2016

7. Shaffey Dave, Ellis-Chdwick Fiona Digital marketing/Pearson Education Limited, 2012 $698 \mathrm{p}$

8. Egol Matt, Peterson Michael, Stroh Stefan How to choose the right digital marketing model//Strategy+business magazine, PwC Strategy\& Inc, Issue 75 summer 2014 [Електронний pecypc] - Режим доступу до ресурсу: http://docplayer.net/18825124-How-to-choose-the-rightdigital-marketing-model.html 
9. [Проникнення інтернету в Україні [Електронний ресурс] // Factum Group Ukraine. 2016. - Режим доступу до ресурсу: https://www.slideshare.net/WatcherUA/iq-2016-ukraineinternet-audience-research?ref=http://biz.liga.net/ekonomika/it/novosti/3300467-proniknovenieinterneta-v-ukraine-vpervye-prevysilo-60.htm]. 